\title{
Translating and Transforming 'Race': Early Meiji Period Textbooks
}

$\operatorname{AUTHOR}(S):$

Takezawa, Yasuko

\section{CITATION:}

Takezawa, Yasuko. Translating and Transforming 'Race': Early Meiji Period Textbooks. Japanese Studies 2015, 35(1): 5-21

ISSUE DATE:

2015-03-25

URL:

http://hdl.handle.net/2433/201836

\section{RIGHT:}

(c) 2015 The Author(s). Published by Taylor \& Francis.; This is an Open Access article distributed under the terms of the Creative Commons Attribution-NonCommercial-NoDerivatives License (http://creativecommons.org/licenses/by-ncnd/4.0/), which permits non-commercial re-use, distribution, and reproduction in any medium, provided the original work is properly cited, and is not altered, transformed, or built upon in any way. 


\title{
Translating and Transforming 'Race': Early Meiji Period Textbooks
}

\author{
YASUKO TAKEZAWA, Kyoto University, fapan
}

Although it is an almost established understanding in European and North American literature that race is a social construct, the general academic and social discourses surrounding race in fapan remain outside this model. This can be traced back to school textbooks and geography books in the early Meiji period, after these concepts and words were translated and introduced from Europe and the United States. This article will examine passages related to race in textbooks from the first half of the Meiji period, in order to explore the continuities and discontinuities in the state of knowledge production surrounding race and racial discrimination in contemporary fapan. Investigating the usage of words in educational practice allows us to see how 'race' was a term that was located in a position different from that of other words, and how the fapanese transformed their racial position in relation to others.

In contemporary Japan the discourse around racism has been framed narrowly to address issues of immediate concern, notably 'ethnic discrimination' (minzoku sabetsu) and 'discrimination against foreigners' (gaikokujin sabetsu), although there is now also an emerging literature that addresses the concept in broader terms. Yet the notion of 'race' structured Japan's development as a nation during both the nineteenth and twentieth centuries. Race as a category has played a key role in domestic and foreign policy alike: Japan's bumpy road to modernization, its so-called 'Leaving Asia, Entering Europe' (datsu-a ny $\bar{u}-\bar{o}$ ) program, and its subsequent empire-building in Asia. ${ }^{1}$ Despite this, the evolution of 'race' (jinshu) in Japanese, as signifier and as signified, has not received the attention it deserves.

Elsewhere, I discuss the three dimensions of race: namely, race ( $r$ ), Race (R), and Race as Resistance (RR). Small-'r' race (r) refers to an indigenously constructed concept where differences between the socially marginalized groups are understood to be inherited through the body, and group hierarchies are associated with political and economic inequality. 'Race as Resistance' ('RR') refers to race as constructed and solidified by these groups, especially their leaders and activist members who adopt essentialized racial identity as a political strategy to fight against racism.

In this essay, I will focus on big-' $R$ ' Race (R), the Western 'scientific' concept that holds that humans can be divided into ontological categories based on perceived bodily features, and which spreads out of Europe and the United States to the rest of the world. Further, I note that each society, after importing or implementing a system of Western 'scientific' classifications, demonstrates not just a 'copy' but its own original

\footnotetext{
${ }^{1}$ See Yamamuro, Shisō kadai toshite no Ajia.
} cited, and is not altered, transformed, or built upon in any way. 
interpretation and system surrounding 'race', dictated by contexts and contemporary needs. ${ }^{2}$ In the case of Japan, the contemporary understanding of race and related terminology found in most dictionaries and school textbooks can be traced back to textbooks and geography books from the early years of the Meiji period, introduced in translation from Europe and the United States. ${ }^{3}$ The late Edo period to the first half of the Meiji period (from around the 1840s through the 1890s) was a time of increased international tension for Japan: European countries as well as the United States were competing throughout the world to expand their territories and power. China, Japan's neighbour, increasingly fell under the sway of Britain after the Opium War (1839-1842) and the Arrow War (1856-1860).

This article will examine geography textbooks from the first half of the Meiji period, focusing on their descriptions of race and its related terminology, as well as some of the Western texts upon which they were based. It aims to explore how 'Race' was both copied and transformed during this critical period for Japan and how knowledge production and circulation took place in the midst of domestic and international turbulence. Although there is some post-1945 literature that discusses race in the Meiji period from various perspectives, ${ }^{4}$ there is, to my knowledge, almost no research that specifically analyses race and related terms in the textbook passages that were used in nationwide school education during the Meiji period. By investigating the usage of words in educational practice, we may see how 'race' was accorded greater attention than other topics, such as language and religion, that were also available within the framework of the discourse.

I argue that the translations into Japanese of material from foreign books did not constitute a mere mimicry of Western knowledge, but that the translations involved deletions and distortions, all with a purpose. This essay shows that, to a significant degree, the process of translating 'race' helped to transform Japan's position in relation to its geopolitical Others. In other words, it demonstrates how the Japanese educational curriculum used the category of race as a tool to jockey for a better position with respect to rival nations on a rapidly Westernizing world stage.

\section{Terminology and 'Race' in Pre-Meiji Japan}

Since the English word 'race' has a number of definitions, there is no single Japanese translation; it varies depending on the context. However, when used to refer to a division of humankind, it is usually translated as jinshu 人種. This word has a complex history, as can be seen below.

The pair of Chinese characters used to express jinshu had existed in Japan for a long time before the advent of modernity there, but with different meanings. For example, the medieval text Shintōsh $\bar{u}$ (c. 1358) uses the word to mean 'the seed of humankind', or simply 'humans'. It is still not known who first deployed this Chinese compound to mean the division of humankind, or when, but by the early nineteenth century, a time of lingering national isolation, it was already being used in that 'scientific' sense. Some researchers have claimed that jinshu in the present sense of the term began to circulate

\footnotetext{
${ }^{2}$ Takezawa, 'Toward a New Approach to Race and Racial Representations'.

${ }^{3}$ While passages on race can also be found in textbooks on other subjects such as world history, I limit my analysis to geography textbooks because these treat the issue in greater detail.

${ }^{4}$ For example, Kudō, Nihon jinshu-ron; Yamamuro, Shisō kadai toshite no Ajia; and Sakano, Teikoku Nihon to jinruigakusha.
} 
around 1890, and that before then it was simply a vague category meaning 'the same kind of people'. ${ }^{5}$ However, such assertions are based only on analyses of the discourses of certain intellectuals. In contrast, nineteenth-century books about foreign countries and geography textbooks after the 1868 Meiji Restoration almost without exception employ the Chinese compound as a general term for categories of humankind, as well as using it (along with plain -shu) as the suffix of the terms for each racial category (e.g., $k \bar{o} k a s a s u-s h u$ or kōkasasu-jinshu for the Caucasian race). ${ }^{6}$

As is well known, 'race' can be also translated with the word minzoku 民族; typical examples include Yudaya-minzoku ('Jewish race'). While there are some instances of minzoku - used in Fukuzawa Yukichi's writings to refer to, for example, a status group (warriors, farmers, craftsmen and tradesmen) collectively and to a 'savage' (ethnic) group in Russia ${ }^{7}$ - in my research I hardly ever found passages where it was used as a translation of 'race' (as the general term for human classification) in early Meiji geography textbooks. This observation is consistent with the arguments of other scholars that minzoku did not circulate in its contemporary sense until the late $1880 \mathrm{~s}^{8}$ The foundation of the magazine Nihonjin (The Japanese) and the newspaper Nihon (Japan), both in 1888, contributed to the nationwide spread of the term minzoku in the contemporary sense. For example, the first issue of Nihonjin starts with an explicitly nationalistic statement invoking the 'over one thousand-year-old tradition of Yamatominzoku [Japanese race/stock] and the Japanese people'. ${ }^{9}$ Thus, the term minzoku had an inseparable relationship with Japanese 'nation' and nationalism, at least in its inception.

Interestingly, the readings of the Chinese character compound now pronounced jinsh $u$ varied. Sometimes the reading for the first syllable $j i$ of the character $人$ (jin) was written using the Chinese character shi 志 with a mark indicating to read it as a voiced syllable, ${ }^{10}$ and other times the compound was read as hitodane. Another reading that appeared once in my survey was hitokusa. ${ }^{11}$ In other words, the readings for this fixed Chinese character compound were unstable. This suggests that the deployment of the Chinese compound for 'race' preceded the reading jinshu.

In earlier Chinese history, the Chinese compound was often used to mean 'bloodline' or 'blood lineage'. For example, it appears in a sentence in fingkangzhuanxinlu (1127) that states that the bloodline of the Chinese emperor will extinguish. However, I was unable to find any examples of the word being used to refer to divisions of humankind in classical Chinese texts which appeared between 1750 and 1840 (the period that starts with the emergence of the human classifications in Europe and finishes with its first known appearance in print in Japan). ${ }^{12}$

\footnotetext{
${ }^{5}$ For example, see Yonaha, 'Kindai Nihon ni okeru “jinshu” kannen no hen'yō'; Sakano, Teikoku Nihon to jinruigakusha.

${ }^{6} \varsigma_{-}-s h$ ' is no longer in use in contemporary Japanese in this context.

${ }^{7}$ Fukuzawa, Seiyō jijō.

${ }^{8}$ See Yamamuro, Shisō kadai toshite no Ajia; Yun, Minzoku gensō no satetsu.

${ }^{9}$ See Yun, Minzoku gensō no satetsu, 38-41.

${ }^{10}$ For a discussion of description of the term in Japanese dictionaries, see Okamura, "Konketsu" o meguru gensetsu'.

${ }^{11}$ In the 1872 text by Kanagaki, Sekai miyakoji [Roads to the World's Capitals], the reading hitokusa is provided in a phrase found in a passage on Africa: 'the black savage race [hitokusa] of the equator'.

${ }^{12}$ I searched the Database of Chinese Classic Ancient Books, a database of over 10,000 Chinese book titles from pre-Qín (778 -206 BC) to the Republican period (1912-1949), for cases of the compound appearing in print in China between 1750 and 1840. See Beijing Airusheng shuzihua jishu yanjiu zhongxin, Zhongguo jiben guji ku. I thank Mochizuki Naoto for assisting this research in Chinese.
} 


\section{Yasuko Takezawa}

According to Katō Shūichi, it was a common practice to introduce European and American words into Japanese by borrowing the corresponding translated terms already used in Chinese. Katō attributes intellectuals' considerable success translating Western books on such a massive scale between the late Edo period and the beginning of the Meiji period (mostly between the 1850 s and 1870s) to this approach. ${ }^{13}$ It is plausible that a translator or translators first introduced the Chinese 人種 into Japanese as 'race' in the sense of human divisions, and that it gained circulation before 'jinshu' became the standard reading. However, it was not until the beginning of the twentieth century that Liang Qichao and other Chinese intellectuals who studied in Japan during the early Meiji period introduced the terms renzhong 人種 and minzú 民族 into Chinese from Japan, along with other terms associated with Western science and civilization. ${ }^{14}$

In the various writings, paintings, and maps produced in Japan after the arrival of missionaries and traders from Portugal, Spain, and other European countries in the sixteenth century and later, we can see what left an impression on these writers and painters about these visitors. ${ }^{15}$ In terms of physical features, the texts emphasize Europeans' big, round eyes, pointed noses, and red hair. Interestingly, there is no mention of skin colour. ${ }^{16}$ According to John Russell, images of black people in Japan were not necessarily negative before the introduction of Euro-American prejudice towards them during the Meiji period. ${ }^{17}$ Prior to the Meiji period, the existence of 'people with red hair' (Europeans), 'black people' (Africans), and 'black boys' (Indonesians who came with the Dutch) was known even among many ordinary people in Edo (Tokyo), who were encountering them on the streets of the city. However, at the time there was no concept used to classify human beings based on skin colour.

One of the first Japanese intellectuals to publish discussion of European human divisions using jinsh $u$ as the translation for 'race' was Watanabe Kazan, the late Edo period painter, man of letters, and devotee of Dutch learning. In Shinkiron [A Private Proposal], published in 1838, 30 years before the Meiji Restoration, he was already arguing that humankind is divided into 'Tartar', 'Ethiopian', 'Mongolian', and 'Caucasian' groups, ${ }^{18}$ drawing on ideas of Linnaeus and Johann F. Blumenbach. At this point, Kazan does not associate the Japanese with the 'Mongolian race', asserting instead that 'our country belongs to the Tartar race'. ${ }^{19}$ However, the influence of Blumenbach's five categories in his 1839 Gaikoku jijosho [Report on Conditions in Foreign Countries] is more pronounced; there he writes, 'The race east of the Caspian Sea $<$ In the theories of Westerners, they are called the Mongolian race and also the Tartar race. Japanese people and Chinese people are both classified as belonging to this race. $>$ has black hair and black eyes, is superior in terms of courage, and led a nomadic life searching for water grass with horse-drawn carriages. ${ }^{20}$

\footnotetext{
${ }^{13}$ Katō, 'Meiji shoki no hon'yaku'. See also Haag, 'Maruyama Masao and Katō Shūichi on Translation and Fapanese Modernity'; Maruyama and Katō, Hon'yaku to Nihon no kindai.

${ }^{14}$ Ishikawa, 'Kindai higashi Ajia "bunmeiken” no seiritsu'; Sakamoto, 'Chūgokushijō no jinshu gainen o megutte'.

${ }^{15}$ For discussions of Western visitors' perceptions of the Japanese during the Edo period, see Maki, Seiyōjin no mita Nihonshi.

${ }^{16}$ For example, see Screech, Öedo Ijin ōrai; Wagatsuma, 'The Social Perception of Skin Color in Japan'.

${ }^{17}$ Russell, 'Excluded Presence'.

${ }^{18}$ Watanabe, Shinkiron, 69.

${ }^{19}$ Ibid. Watanabe Kazan is usually called by his given name (Kazan), unlike writers and others from the Meiji period onwards, who are known by their surnames.

${ }^{20}$ Watanabe, Gaikoku jijōsho, 18-19.
} 
Kazan, turning his gaze overseas to write widely about conditions in foreign countries, was not simply driven by curiosity. He states, 'All the five continents on the earth with the exception of Asia belong to Europe. Furthermore, within Asia, only the three countries of China, Persia, and our country have avoided the "defilement of Westerners". ${ }^{21}$ This passage reveals his anxiety about Europe's expanded colonialism and possible incursions in East Asia, as well as the shadow of Europe that loomed over Japan. $^{22}$

\section{First Decade of the Meiji Period (1868-1877)}

Immediately following the Meiji Restoration, the new government launched a series of urgent modernization projects, one of which was the comprehensive spread of elementary education, intended to 'eliminate uneducated households'. ${ }^{23}$ In 1872 a public education system was established based on models from the advanced West. The system was subdivided into higher, middle, and elementary education, and the entire country was divided into districts, each containing one elementary school. Because of the scarcity of introductory books on geography at the time, the 'Rules for Elementary School Education' (shōgaku kyōsoku) designated the following as geography textbooks: Uryū Tora's Nihon kunizukushi [Account of the Country of Japan, 1872], Fukuzawa Yukichi's Sekai kunizukushi [Account of the Countries of the World, 1869], Matsuyama Tōan's Chigaku kotohajime [Beginning Geography, 1870], Ichioka Masakazu's Kōkoku chirisho [Imperial Geography, 1874] and Uchida Masao's Yochishiryaku [Condensed Geography, 1870]. Since Nihon kunizukushi and Kökoku chirisho focus only on Japanese domestic geography, they will be excluded from the following analysis.

Many (partial) translations were published of foreign geography textbooks. Chigaku kotohajime mentioned above, which contains selected translations from several American geography and history books, states that people can be divided into five races based on 'cranium shape and skin shade', reflecting Blumenbach's influence. The Ministry of Education compiled information on Japanese geography and foreign geography at the Shihan Gakkō (Tokyo Normal School), the top teacher training program at the time, and published official textbooks. Of these, the three-volume Bankoku chishiryaku [Condensed World Geography, 1874] served as a foreign geography textbook for Japanese schools.

Sekai kunizukushi, a best-seller of the time and later employed as a geography textbook, and Yochishiryaku, another very popular textbook, exerted such an enormous influence that their passages on race and related topics became models for other early Meiji world geography textbooks. One million copies were printed of Sekai kunizukushi. ${ }^{24}$ As for Yochishiryaku, the Ministry of Education reported that as many as 150,000 copies had been already printed by 1874-1875 and later more with new editions.

Yochishiryaku was a government-published world geography textbook based on the texts the Ministry of Education bureaucrat Uchida Masao had collected at the end of the Edo period while studying abroad in the Netherlands and later travelling around the world. Almost half of the illustrations in the book copied ones found in Tour du Monde:

\footnotetext{
${ }^{21}$ Watanabe, Saikō seiyō jijōsho, 49.

${ }^{22}$ See Satō, 'Watanabe Kazan to Takano Chōei', 631.

${ }^{23}$ Nakagawa, Kindai chirikyōiku no genryū, 11.

${ }^{24}$ See Nakamura, Kyōkasho no shakaishi, 5.
} 
nouveau journal des voyages, published in the middle of the nineteenth century. ${ }^{25}$ The book was designated as the 'Geography Reading Seminar' textbook for higher elementary education from fifth to eighth grade. In fact, it was also used as the geography textbook at the Tokyo Normal School.

Yochishiryaku lists 'Gōrudosumisu' in the introduction as an author of one of the major works consulted in its creation, probably a reference to the London missionary J. Goldsmith, the author of $A$ Grammar of Geography for the Use of Schools, with Maps and Illustrations, a series widely used as geography textbooks in English elementary schools. ${ }^{26}$ Goldsmith's book describes the approximate populations of the world's five continents under the heading 'Race Categories', with details of the area of inhabitation, population, physical characteristics, and the stages of civilization of the 'five races': Mongolian, Caucasian, Ethiopian, Malay, and American. ${ }^{27}$ As was the case in overseas geography textbooks at the time, in contrast to the passages on China and Chinese people that occupied many pages, there was limited information on Japan in Goldsmith's book. This section of the book contains a single brief sentence on the country: 'The people have a considerable degree of civilization and skill in manufacturing. ${ }^{28}$ Yochishiryaku also lists China, Siberia, and Turkey as 'half-civilized' countries, and European countries and the United States as 'civilized' countries. It defines 'half-civilized' countries as having a constitution, land de-privatized by a sovereign, and so on.

Fukuzawa's Sekai kunizukushi mostly contains translations of important sections of world geography and history books published in the US and England, purchased during the author's travels abroad at the end of the Edo period. ${ }^{29}$ Each of the first five volumes is devoted to one of the five continents of the world (Asia, Africa, Europe, [North and South] America, and Australia), and provides information relating to race, nations, geography, history, and lifestyles. It divides the people of the world into four categories. The first category, 'chaos' (konton), is described as the 'most inferior people', said sometimes to 'eat human flesh', fight with each other, and to be illiterate, lawless, and unmannered. The 'natives' (dojin) of Australia and inner Africa are presented as examples. The second category, 'barbarian' (ban'ya), consists of people 'one stage above savage people', such as Tartars who live in northern China, and 'natives' of Arabia and northern Africa. The third category is entitled 'as yet uncivilized [mikai] or half-civilized [hankai]'. Finally, the fourth category, 'civilized' (bunmeikaika), consists of people who value manners, are moderate in their emotions, and actively engage in academics, the arts, and farming. The United States, England, France, Germany, and the Netherlands are presented as ideal examples. ${ }^{30}$

These stages of civilization found in Sekai kunizukushi became the model for the discussion of the civilization stages that appeared in some of the Japanese geography textbooks, which often included sections entitled 'Stages of Civilization' (bunmei no $t \bar{o} k y \bar{u}$ ) comprising sub-sections such as 'Barbarian' (ban'i), 'Not Yet Civilized', 'HalfCivilized' and 'Civilized'. Generally, each sub-section included a simple definition of the respective stage, and names of example countries.

\footnotetext{
${ }^{25}$ See Masuno, 'Mieru minzoku mienai minzoku', 50-51; Nakagawa, Kindai chirikyōiku no genry $\bar{u}, 46$.

${ }^{26}$ These geography textbooks usually came in multiple versions, or had similar books with different titles. See Sitwell, Four Centuries of Special Geography.

${ }^{27}$ Goldsmith, A Grammar of Geography for the Use of Schools.

${ }^{28}$ Ibid., 103.

${ }^{29}$ Fukuzawa does not list the titles of the books he used.

${ }^{30}$ Fukuzawa, Sekai kunizukushi, 64.
} 
Fukuzawa describes the purpose of the book as follows: 'It can be easily imagined that the source of fortune and misfortune under heaven is nothing other than the intelligence and stupidity of the people. It is my sole hope that this book Sekai kunizukushi makes mainly children and women understand the formation of the world, opens the door to this knowledge, and thereby establishes the basis of welfare and happiness under heaven [天下幸福]. ${ }^{31}$ Furthermore, he also proclaims, 'Dividing the world into five races, their levels of intelligence are not the same, and likewise countries' customs and industry are not the same. ${ }^{32}$ In other words, it seems he thought that by acquiring knowledge regarding the people of the five races of the world and mimicking the lifestyles and temperaments of those belonging to civilized countries, Japan would become civilized, strong, wealthy, and 'happy under heaven' overall. It is possibly for this reason that the book provides details regarding standards of living and temperaments, and gives less attention to topography and climate.

Fukuzawa departed from the usual practice of his Western sources, instead making Asia the subject of the first volume in his series, which featured descriptions and illustrations of China and the Chinese. There he also discussed China's defeats at the hands of the British, the associated indemnity payments, and the transfer of Hong Kong to Britain. He argued that the country 'in the end earned the contempt of other countries because there were truly no people who held patriotic thoughts'. ${ }^{33}$ Fukuzawa was urging a sense of crisis in the children who would be the bearers of Japan's future and the women responsible for raising them, and connected this alarm to the cultivation of patriotic spirit. In other words, with the encroachment of Western powers in mind, Fukuzawa thought that Japan's future - either falling to the same fate as China or 'entering Europe' by attaining civilization of the same level as Western nations - depended on whether common people would take an interest in their country's path forward and respect the arts, sciences, and learning in the home.

As mentioned earlier, in the decades before and after the Meiji Restoration, a considerable number of Western books were translated and published. One of them was Hyakka zensho Finshu-hen [An Encyclopaedia of Race, 1874], a translation by Akiyama Tsunetarō of the chapter 'Physical History of Man - Ethnology' from Chambers's Information for the People, an English textbook widely used in Europe and America. ${ }^{34}$ There are five editions of the 'Chambers's Information' series, ${ }^{35}$ but Ishikawa Yoshihiro's claim that the new and improved edition published in Philadelphia was used for Akiyama's translation is most convincing. ${ }^{36}$ This text draws from the work of leading students of race of the time such as Johann F. Blumenbach (Germany), Georges Cuvier (France), James Cowles Prichard (Britain), and Daniel G. Brinton (United States), and symbolically marks the beginning of the study of race in Japan. The book

\footnotetext{
${ }^{31}$ Ibid.

${ }^{32}$ Ibid., 154.

${ }^{33}$ Ibid., 97.

${ }^{34}$ Akiyama, Hyakka zensho Finshu-hen; Chambers, Chambers's Information for the People.

${ }^{35}$ Chambers Publishers, founded by William Chambers and Robert Chambers, published many series of edifying books. Ones such as 'Chambers's Educational Course', which they began to actively publish in 1835, served as an important model for the books of late Edo and early Meiji intellectuals who had a strong interest in Western science and cultural knowledge, such as Fukuzawa's Seiyō jijō gaihen [Conditions in the West, 1867] and Dōmō oshiegusa [Lessons for Children, 1872].

${ }^{36}$ Although there are various theories regarding which version was used for the translation, I concur with Ishikawa's assertion that it was the new and improved version published in Philadelphia in the United States in 1867. Ishikawa, 'Kindai nitchū no hon'yaku hyakkajiten ni tsuite'. See also Matsunaga, 'Kaisetsu: Chenbāzu infomeshion to monbushō Hyakka zensho ni tsuite'.
} 
served as a model for discussions of race in Japanese textbooks and most likely contributed to the spread of the word jinshu.

The translator made various modifications to the text, including the title: the Japanese Finshu-hen is different from the original 'Physical History of Man - Ethnology'. Furthermore, he chose to deal with the English word 'variety' by translating it with the Chinese compound jinshu, ${ }^{37}$ and placing a katakana reading guide above it to show that it was to be read as 'viritii' (variety). While it is unclear to what extent Japanese geographers and intellectuals understood the fundamental difference between 'variety' and 'race' as categories for classifying humans, at the very least we can see that the word jinshu as a term for divisions of humankind had already to some extent become established in the time between Watanabe Kazan and the early Meiji period.

While no definitive conclusions can be drawn, due to the absence of one-to-one translations, the following can be pointed out based on examination of the textbooks in this period. ${ }^{38}$ First, in almost all books on the geography of foreign countries published during the first ten years after the Meiji Restoration that I consulted, the section on 'Racial Distinctions' occupies an important place, generally appearing at the beginning, immediately after a discussion of the overall world population. Judging from their forewords and explanatory notes, it was the geography textbooks of the Americans Cornell and Mitchell and the British Goldsmith that were most often used as source texts. ${ }^{39}$ Secondly, since geography books specifically on Japan were being published separately at the time, these translation-based texts normally omit passages about Japan and are structured to provide dispassionate objective information on other countries' geography, population, race, customs, and so on. Furthermore, in the passages on the Mongolian race, many books, if not all, provide stereotypical illustrations of Chinese people, portraying them with pigtails and traditional clothes. In the same way, in the early Meiji period, with civilization (bunmei) being lavishly praised, 'civilized' European countries were extensively discussed in geography textbooks. While Japanese intellectuals regarded the Japanese as more civilized than the Chinese, a view bolstered by the social upheaval the latter were undergoing at that time, the passages on stages of civilization do not clearly assign Japan to either the category of civilized or of halfcivilized (the one used to describe China and some other Asian countries). As a result, the readers of these books remained for the most part unaware of how Europe's and America's gaze positioned Japan within the different stages of civilization.

\section{The Second Meiji Decade (1878-1887)}

From around the beginning of the second decade of the Meiji period, people started to view with scepticism and criticize the translation-based approach to textbook creation. Many textbooks published in this decade reflected a Japanese-centric perspective of the world and the country's domestic social background. Indeed, even Yochishiryaku, which in its earlier editions $(1871,1875,1879$, and 1880) mentioned very little about Japan,

\footnotetext{
${ }^{37}$ Johann F. Blumenbach, who is presented as the source of human classifications in the general overview section of the 'Jinshu-hen', adopted the Latin word varietate ('variety') based on the idea that the five human divisions were nothing more than variations. However, jinshu - generally the translation of 'race' is used in the textbook, implying the existence of fixed categories.

${ }^{38}$ These tendencies are also found in Sugawa, Bankoku chirishi, which lists Mitchell's Geographical Reader: A System of Modern Geography as its primary source text.

${ }^{39}$ However, the translated texts frequently do not provide the publication years and titles of their sources.
} 
included in the 1882 edition a statement filled with considerable pride regarding Japan's civilization: 'The civilization of our country has from a long time ago extended from its western corner to its eastern corner. ${ }^{40}$

Among the original textbooks newly created around the end of the 1870 s and in the early 1880 s to meet the demand for independent Japanese pedagogy, several touch upon the emperor and his lineage. Shinsen chiri shoshi [A Newly Compiled Elementary Account of Geography, 1879], for example, contains the phrase, 'The emperors of Japan are one unbroken line [bansei ikkei] ${ }^{41}$ In a similar vein, Yochishiryaku (1879) asserts that 123 generations of emperors had existed since Emperor Jinmu. ${ }^{42}$ Patriotism was introduced into geographical education through the notion of the 'one unbroken line' in an attempt to strengthen the foundation of an emperor-centric nation-state.

Haruperu-shi no chishi [Mr Harper's Geography Textbook], listed as a source text in Bankoku chirishi (1877) and other textbooks, appears to refer to Harper's School Geography, With Maps and Illustrations. ${ }^{43}$ In the 1878 and 1886 editions of Harper's I have consulted, the 'Conditions of Society' section divides people based on their 'social condition' into the five stages of savages, barbarians, half-civilized nations, civilized nations, and enlightened nations. Here, the concept of 'enlightened' extends that of 'civilized'. They are distinguished in the following way:

Civilized nations are those that engage in commerce, practice the art of writing, and have made considerable progress in knowledge and morality. Enlightened nations are those civilized nations that possess a thorough division of labor, have established general systems of education, and have made the greatest progress in knowledge and morality. ${ }^{44}$

Immediately after these definitions, it states, 'The enlightened and civilized nations are nearly all Caucasian. ${ }^{45}$ Again, there is no mention of Japan's placement in this gradation.

On the other hand, the difference between Japanese people and Chinese people is emphasized in the section on specific countries:

Although the Japanese live so near the Chinese, they are a very different kind of people. They [Japanese] are more intelligent, and do not have so many odd notions. The Chinese dislike foreigners, and have learned very little from them; but the Japanese welcome Americans and Europeans, and make use of their inventions, such as railroads and telegraphs. ${ }^{46}$

The pride of geographers and intellectuals in Japanese civilization must have grown deeper upon encountering somewhat favourable passages on Japan in similar texts and

\footnotetext{
${ }^{40}$ Fujiya, Yochishiryaku, 30.

${ }^{41}$ Yamada, Shinsen chiri shōshi kan-ni.

${ }^{42}$ Ibid., 29. Historians have shown that this discourse was one of the 'invented traditions' of the Meiji period.

${ }^{43}$ Harper \& Brothers, Harper's School Geography, With Maps and Illustrations. This mention in Bankoku chirishi implies, of course, that an edition of Harper's School Geography was published before 1877, but I am as yet unable to confirm this.

${ }^{44}$ Harper \& Brothers, Harper's School Geography, With Maps and Illustrations, 18.

${ }^{45}$ Ibid.

${ }^{46}$ Ibid., 99.
} 


\section{Yasuko Takezawa}

interpreting that Europeans and Americans saw distinct differences between their country and China.

It is noteworthy that some of the Japanese textbooks include the category 'Other Civilized Countries', ones said to have constitutions and land de-privatized by a sovereign. Furthermore, China was often presented as half-civilized and Europe and America as civilized. At present it is unclear whether translators carried over the category 'Other Civilized Countries' from a source text or added it on their own. At the very least, considering that it does not appear in any of the main source texts listed in the textbooks, it is highly likely they had specific reasons for including it. While Japan is not explicitly named as one of these countries, it appears that readers were expected to conclude that this is where it belonged.

These passages may be a reflection of the Social Darwinism that was also spreading among intellectuals in Tokyo in the early 1880s, and which allowed Japanese intellectuals and education officials to interpret civilization as something attainable by their country, not the sole attribute of white nations.

\section{The Third Meiji Decade (1888-1897)}

From this decade onward, an approach to teaching geography that aimed at the prosperity and the strength of the state emerged. This was explicitly outlined in the 1891 'Fundamental Principles of Education' (kyōsoku taikō): 'Additionally, the spirit of patriotism will be cultivated. ${ }^{47}$ Also, Bankoku chishi (1896) and other textbooks aimed to do away with the translation-based early Meiji style of world geography textbooks, arguing that 'previous textbooks, most of which have been translation-based from European and American geography books, [would be appropriate] for European and American students and not suitable for the students of our country', and proposing instead to 'have [students] study overseas geography in a Japanese way as far as possible'. ${ }^{48}$

Early Meiji period textbooks generally do not make clear the relative civilizational level of Japanese people. However, during this period, an elaboration of racial categorizations that went beyond Blumenbach's five categories began to spread throughout the country. This can be clearly found in textbook passages that group the Mongolian race and Japanese people with the Caucasian race - distorted interpretations markedly different from the various theories of European racial studies.

People of the Caucasian and Mongolian races, who live in the moderate northern climates, are the most civilizationally progressed, and are powerful. .. ${ }^{49}$

Within the five races, the two races of Europe and Asia are advanced in their knowledge and are civilized or half-civilized, while the other three races are generally ignorant and unenlightened, with many of their people being uncivilized savages. ${ }^{50}$

\footnotetext{
${ }^{47}$ Arimoto, 'Senzen chirikyōiku no bunseki'.

${ }^{48}$ Yazu, Chügaku Bankoku chishi, 1.

${ }^{49}$ Yamada, Shinchishi, 8.

${ }^{50}$ Hata, Chūtō kyōiku Bankoku chishi, 20; see also Shibue, Kōtō shōgaku Bankoku chiri, 64.
} 
Taken together, these passages associate both the races of Europe and Asia with 'knowledge', 'progress', and 'power' as well as 'civilization'. By rejecting the clear binary opposition schema 'white races vs. coloured races' that was seen as self-evident in Europe and America and grouping together the 'Caucasian race' and 'Mongolian race' ('Asian race'), a new re-formulated interpretation posited the existence of these two races and 'the other three races'. Furthermore, some other textbooks distinguish Japanese and Chinese from the rest of the Mongolian race, emphasizing the superiority of the former two. A variant of this can be found in Shoggaku Bankoku chishi, which positions Japanese and Chinese people at the top of the Mongolian race in the world hierarchy, stating '[Among the Mongolian race,] we Japanese as well as the Chinese are ... the most advanced'. ${ }^{51}$

Beginning around this time, Japanese textbooks began increasingly to exalt the Japanese people.

As for the European race, ... its culture is the most progressed, and they are the most powerful ... As for the Asian race, its power has generally declined, with the exception of our Yamato race $[$ minzoku] ... As for the African race ... there are many who have still not escaped from an ignorant and savage state. ${ }^{52}$

Eventually, these passages came to state that only the Yamato race was equal to the European race or that only the Japanese were superior to other Mongolian races. The following passage again mentions the moderate climate (seen earlier in Yamada's 1893 text), which was around that time taken as one indicator of the country's ability to produce a superior civilization.

By learning about the various countries of the world, we know how our empire excels more than other countries of the world. By learning about the natural features [of our empire], we know in what way its nature and natural features are beautiful, and in what way its climate is moderate. ${ }^{53}$

The Japanese, although belonging to the Mongolian race according to racial divisions [jinshu no kubetsu-jō], are superior to other Mongolians, tending to prize $c h \bar{u}$ [loyalty], $k \bar{o}$ [filial piety], and shingi [faith]. ${ }^{54}$

This cultivation of a patriotic spirit grew stronger in the discourse surrounding 'bloodline'; for example, Nihon teikoku seiji chiri (1893) asserts, 'Since the race of our empire generally originates from the same bloodline, the idea of the Japanese race has solidified'. 55

It is around this period that mentions of the 'Aryan race' started to appear frequently in textbook passages. ${ }^{56}$ For example, Chütō kyōiku joshi chiri kyōkasho (1888) contains an explanatory note: 'The race that has reached the highest level in the advancement of

\footnotetext{
${ }^{51}$ Miyake, Chūgaku Gaikoku chishi, 27; see also Kinkōdō shosekikaisha henshūjo, Shōgaku Bankoku chishi, 37.

${ }^{52}$ Chiri Kenkyūkai, Shinchiri chūgakkōyō gaisetsu nobu, 78-79.

${ }^{53}$ Yazu, Chügaku Bankoku chishi, 2-3.

${ }^{54}$ Yamada, Shinchishi, 8.

${ }^{55}$ Yazu, Nihon teikoku seiji chiri, 417. This book was intended 'not only as a textbook for secondary education but also to meet the needs of a wider society'; ibid., 1.

${ }^{56}$ Since unlike early Meiji translation-based textbooks there are no clues as to the texts consulted, the source of the term 'Aryan race' and the meaning attached to it are hard to pinpoint.
} 
human knowledge is the one that has expanded from India to Europe... it is called "Aryan" or India-European race'. ${ }^{57}$ It is of interest that Nihon teikoku seiji chiri, while mentioning that scholars have not necessarily agreed on the race the Japanese belong to, states the following:

although it is generally believed that most of the Japanese belong in the Mongolian race category, some argue that [our] people belong with [the inhabitants of] the southern islands [nanpo shotō], while others claim that the Japanese race is one variety of Caucasian. ${ }^{58}$

The latter likely referred to Taguchi Ukichi, who had already aired his views in public by then and would soon publish his theory on the Japanese race, in which he argued, using a linguistic-genealogical approach, that the Japanese race was part of the Aryan language-speaking group, but also that it was in fact 'superior, not only to the Chinese race, but to the Aryan race as well from which he argues the Japanese race derived'. ${ }^{9}$ This adoption and modification was partly due to the influence of late nineteenthcentury European race science, some versions of which attempted to subdivide and hierarchize the European race. ${ }^{60}$

The passages above reflect a shift from a world geography for the acquisition of knowledge about foreign countries to one for instilling the superiority of Japan in students. More importantly, this use of textbooks was the reflection of what, in a different context, Charles Ingrao calls 'weapons of mass instruction', ${ }^{61}$ teaching materials employed to advance Japan's nascent nationalism. That is, by relocating the origin of the 'civilization' from Europe to Asia, the intellectual elites undertook the realignment and repositioning of Japan in the world racial hierarchy.

\section{Concluding Remarks}

In this essay, I examine geography texts published between the end of the Edo period and the decade of the Meiji 20s (the 1860s to the 1890s), primarily focusing on passages on race and related terms in world geography textbooks. While the discursive position of the few textbooks that did exist during the early Meiji period is clear, the extent of the influence of individual textbooks grows ambiguous as their numbers increase over the years.

However, despite these issues, this essay shows the transformations in the roles and discursive content of textbooks on overseas geography in various time periods. From the late Edo period to directly after the Meiji Restoration (mostly between the 1840s and 1860s), when the country was experiencing the upheaval that accompanied moving from a policy of seclusion to engagement with the outside world, intellectuals felt it increasingly urgent that Japan avoid falling victim to the expanding power of Western countries. Thus, it was their utmost priority to share the knowledge regarding conditions

\footnotetext{
${ }^{57}$ Fujiya, Chūtō kyōiku joshi chiri kyōkasho, 149-50. See also Yazu, Chūgaku Bankoku chishi, 11.

${ }^{58}$ Yazu, Nihon teikoku seiji chiri, 417.

${ }^{59}$ Taguchi, 'Nihon jinshu ron', 141; see also Taguchi, 'Kokugogaku yori kansatsu shitaru jinshu no shodai'.

${ }^{60}$ For example, see Ripley, The Races of Europe.

${ }^{61}$ Ingrao, 'Weapons of Mass Instruction'.
} 
overseas that they had obtained from Dutch studies (rangaku 蘭学), missionaries, and their travels in Europe and America.

The new Meiji government adopted translation-based texts that drew from common European and American textbooks and compiled texts to be used in the country's emerging educational system. As if attempting to make up for the ignorance caused by the country's centuries-old policy of seclusion, these texts typically began by presenting information on categories used to classify the earth's inhabitants, as well as their appearance, character, ways of life, numbers, and levels of civilization. In fact, teachers spent a considerable amount of time on foreign geography in ordinary elementary school classrooms. For example, the Elementary School Education Platform of 1881 required the fifth graders to spend six hours per week on foreign geography in the last half of their year but three hours per week on other genres of geography. ${ }^{62}$ The texts they used emphasized race above all else, followed by language and religion. This early Meijiperiod foreign geography education can be seen as a response to the expansion of people's interest in the world that formed the basis for the construction of the worldview of modern Japan.

Amidst the rush to create a civilized country, one of the primary issues of interest to geographers and people associated with the Ministry of Education was 'stages of civilization', a topic connected to race. Through translated knowledge, they uncritically adopted the racial hierarchy of Europe and America that asserted a large gradational gap between the illiterate and putatively savage natives of Africa and Australia and the fully civilized Caucasian race of Europe and America, and filled the space in between with 'not-yet civilized' and 'half-civilized' stages.

Furthermore, the category 'Other Civilized Countries', which was not found in any of the major foreign textbooks, started to be put forward. While 'Japan' is not explicitly named as one of these countries, it appears that readers were expected to conclude that this is where it belonged. After all, China was presented as half-civilized and Europe and America as civilized. This implicit inclusion may have been intended to imply that even if Japan had not reached a point at which it could be declared a civilized country, the attainment of this status, depending as it did on the actions of the people of the nation, was not far ahead.

Compared to later textbooks about world geography, Japan receives little attention in those from the early Meiji period (even if we take into account the fact that Japanese domestic geography textbooks also existed). Few of them clearly state that Japanese people belong to the Mongolian race, a reflection of the fact that the theory which viewed the Japanese people in this way had not yet become widely established. In fact, at the time there were a variety of theories circulating in Japanese academia regarding the Japanese race: one held it to be a mix of the Mongolian race, Malay race, and Ainu 'tribe' (shuzoku), another a combination of races from the northern and southern parts of the Japanese archipelago, and one more a hybrid of the Ainu, Malay race, and Jewish people. ${ }^{63}$

By the third decade of Meiji, school geography textbooks in Japan had come to include passages clearly stating that Japanese people were Mongolians, and to instil in their readers an awareness of Japan's endowments in terms of its natural features and the superiority of its people. In these passages, the Euro-American 'white races vs. coloured races' dichotomy became 'the white race and the Mongolian race vs. other races'.

\footnotetext{
${ }^{62}$ Kaigo and Naka, 'Chirigaku kyōkasho sōkaisetsu', 600

${ }^{63} \mathrm{Kudō}$, Nihon jïnshuron; Iikura, Ierō periru no shinwa
} 
However, just as some European theories of racial classifications started to posit the existence of a hierarchical order within the 'races of Europe' in the late nineteenth century, there were some texts that asserted the superiority of Japan and China within the 'races of Asia', and later that of Japan only, as China came to be relegated. We could say that Japanese textbooks provided 'weapons of mass instruction', to advance Japan's nascent nationalism as well as to construct the subject of Japan, which was emerging as an increasingly confident country due to its growing power.

Not all textbooks published between the early Meiji period and the end of the century extolled the superiority of Japanese people. ${ }^{64}$ The influence of Europe and America's racial theories being large, some individuals in Japan uncritically adopted the discourse that saw the Japanese as racially inferior to white people. ${ }^{65}$ However, doubts about white supremacism began to appear during this period as well. Some intellectuals and scholars were gaining recognition for their assertion of Japanese superiority as Japan's sound economy and national confidence were growing. In the narrow space between EuroAmerican-influenced racial theories that saw the Japanese as racially inferior and these sceptics, Japan began to toggle between Westernization and de-Westernization.

After being introduced from Europe and the United States, 'race' was interpreted and transformed in Japan in relation to supposed stages of civilization, the non-physical, invisible marker. The highest stage was seen as attainable by lower-ranked countries especially Japan. Skin colour and head shape, which were visible, essential markers and devices used to justify colonialism in Europe and the United States, never had the same significance in Japan. This discrepancy in the understandings of race and civilization between Japan and the West reached its culmination when Japan's Racial Equality Proposal, which attempted to address legal racism against Japanese immigrants on the west coast of the United States, was rejected by the United States and its allies at the 1919 Paris Peace Conference. The great disappointment made Japan finally recognize that the dream of joining the ranks of Europe and America - asserted as a possibility in some textbooks - was unattainable.

After World War II, hierarchy-based discussions of race and civilization completely disappeared from school textbooks, although terminology such as Caucasoid, Mongoloid, and Negroid remained. Race came to be simply presented as a way to divide humankind based on phenotypic features. Japan has not yet fully succeeded in rejecting race as a biological reality and reconsidering race and racism from the social constructionist perspective that shifted the view of race in Euro-American literature in the last decades of the twentieth century. This out-dated reproduction of discourses on race has prevented a full understanding of 'racism' against phenotypically indistinguishable groups such as the Koreans and the Burakumin, who continue to be racialized in contemporary Japanese society.

\footnotetext{
${ }^{64}$ See for example, Noguchi, Chūtō kyōiku Chiri kyōkasho; Nakamura, Chūtō Chiri. More archival materials on these textbook authors would provide deeper insight into their mindset and agendas. Further research in this area needs to be undertaken.

${ }^{65}$ Theories of racial improvement were actively discussed at the end of the 1870 s. Sometimes these discussions ballooned into large debates. For example, Takahashi Yoshio, then a journalist with close ties to Fukuzawa Yukichi, recommends in Nihon jinshu kairyorron that the Japanese race be improved through inter-marriage of Japanese people and foreigners living in Japan. In contrast, Katō Hiroyuki, then the President of Tokyo Imperial University, argued in his 'Jinshu kairyō no ben' (A Speech on Racial Improvement) not for racial improvement based on mixing but for maintaining Japanese purity through education, nutrition, and so on.
} 


\section{Acknowledgements}

I would like to thank the anonymous reviewers and journal staff for their insightful and extremely helpful comments. My thanks also go to David Kelly, Brian Locke and Dylan Luers for their editorial assistance. This research project was supported by Grant-in-Aid for Scientific Research (S) 22222003.

\section{References}

Akiyama Tsunetarō, trans., Hyakka zensho finshu-hen [Encyclopedia: Race]. Monbushō, 1874.

Arimoto Yoshihiko, 'Senzen Chirikyōiku no bunseki' [An Analysis of Geography Education in the Prewar Era], in Kyōiku kagaku kenkyūkai shakaikagaku bukai, Shakaika kyōiku no riron. Mugi Shobō, 1966.

Beijing Airusheng shuzihua jishu yanjiu zhongxin, Zhongguo jiben guji ku [Database of Chinese Classic Ancient Books]. Beijing: Beijing Airusheng shuzihua jishu yanjiu zhongxin, 2011. http://server.wenzi base.com/dblist.jsp.

Chambers, William and Robert Chambers, Chambers's Information for the People, New and improved edition. Philadelphia: J.B. Lippincott \& Co., 1867.

Chiri Kenkyūkai, ed., Shinchiri Chūgakkōyō gaisetsu nobu [Geography for Junior High School]. Bungakusha, 1913.

Fujiya Takao, trans., Chūtō kyōiku joshi chiri kyōkasho dai 1 chitsu [Keith Johnston's A School Physical and Description Geography]. Uchida Rōkakuho, 1888-1890.

Fukuzawa Yukichi, Seiyō jijō [Western Affairs], in Nakagawa Shin'ya, ed., Fukuzawa Yukichi chosakushū 1 kan. Keiō Gijuku Daigaku Shuppankai, 2002 [1866].

Fukuzawa Yukichi, ed., Seiyō jijō gaihen [Conditions in the West]. Shōkodō, 1867.

Fukuzawa Yukichi, trans., Sekai kunizukushi, zen roku-kan [All the Countries of the World, six volumes]. Keiō-gijuku, 1869.

Fukuzawa Yukichi, 'Dōmō oshiegusa' [Lessons for Children], in Nakagawa Shin'ya, ed., Fukuzawa Yukichi chosakushū 2 kan. Keiō Gijuku Daigaku Shuppankai, 2002 [1872].

Goldsmith, J., A Grammar of Geography for the Use of Schools, With Maps and Illustrations. London: William Tegg, 1868.

Haag, Andre, 'Maruyama Masao and Katō Shūichi on Translation and fapanese Modernity', in Indra Levy, ed., Translation in Modern Fapan. London: Routledge, 2010, 15-43.

Harper \& Brothers, Harper's School Geography with Maps and Illustrations. New York: Harper \& Brothers, 1886.

Hata Masajirō, Chūtō kyōiku Bankoku chishi [Secondary Education World Geography]. Hakubunkan, 1891.

Ichioka Masakazu, Kōkoku chirisho: Shōgakudokuhon [Imperial Geography for Elementary School]. Kinshōdō, 1874.

Iikura Akira, Ierō periru no shinwa [Myth of the Yellow Peril]. Sairyūsha, 2004.

Ingrao, Charles, 'Weapons of Mass Instruction: Schoolbooks and Democratization in Multiethnic Central Europe', Fournal of Educational Media, Memory, and Society, 1:1 (2009): 180-89.

Ishikawa Yoshihiro, 'Kindai higashi Ajia "bunmeiken" no seiritsu to sono kyōtsū gengo Chō Keiryō ni okeru "jinshu” o chūshin ni' [Liang Qichao, the Birth of the 'Civilization Sphere' in Modern East Asia and Its Lingua Franca], in Hazama Naoki, ed., Seiyō kindai bunmei to chūka sekai. Kyōto: Kyōto Daigaku Gakujutsu Shuppankai, 2001, 25-40.

Ishikawa Yoshihiro, 'Kindai nitchū no hon'yaku hyakkajiten ni tsuite' [On Translations of Encyclopaedias in Modern Japan and China], in Ishikawa Yoshihiro and Hazama Naoki, eds, Kindai higashi ajia ni okeru hon'yaku gainen no tenkai. Kyōto: Kyōto Daigaku Zinbun Kagaku Kenkyūsho Fuzoku Gendai Chūgoku Kenkyū Sentā, 2013.

Kaigo Tokiomi and Naka Arata, 'Chirigaku kyōkasho sōkaisetsu' [Commentary on Geography Textbooks], in Kaigo Tokiomi and Naka Arata, eds, Nihon kyōkasho taikei, kindaihen, dai-17 kan: chiri 3. Kōdansha, 1966, 576-630.

Kanagaki Robun, Sekai miyakoji [Roads to the World's Capitals]. Bankyūkaku, 1872.

Katō Hiroyuki 'Jinshu kairyō no ben' [A Speech on Racial Improvement], in Katō Terumaro, Katō Haruhiko and Mawatari Toshio, eds., Katō Hiroyuki kōen zensh̄u dai-1 satsu. Maruzen, 1900 [1886]. 


\section{Yasuko Takezawa}

Katō Shūichi, 'Meiji shoki no hon'yaku: naze nani o, ika ni yakushita ka' [Translation in the Early Meiji Period: Why, What, and How They Translated], in Katō Shūichi and Maruyama Masao, eds, Hon'yaku no shisō. Iwanami Shoten, 1991.

Kinkōdō shosekikaisha henshūjo, Shōgaku Bankoku chishi [Elementary School World Geography]. Kinkōdō Shoseki, 1894.

Kudō Masaki, Nihon jinshu-ron [On the Japanese Race]. Yoshikawa Kōbunkan, 1979.

Lewis, Martin W., and Kären Wigen, The Myth of Continents: A Critique of Metageography. Berkeley: University of California Press, 1997.

Maki Kenji, Seiyōjin no mita Nihonshi [Japanese History as Discussed by Westerners]. Shimizu Kōbundō, 1968.

Maruyama Masao and Katō Shūichi, Hon'yaku to Nihon no kindai [Translation and Japan's Modernity]. Iwanami Shoten, 1998.

Masuno Keiko, 'Mieru minzoku mienai minzoku Yochishiryaku no sekaikan' [Visible Ethnicity and Invisible Ethnicity: the Cosmology of Yochishiryaku], in Kanagawa Daigaku 21seiki GCOE puroguramu, ed., Hanga to shashin: 19 seiki kōhan dekigoto to imēji no sōshutsu. Kanagawa Daigaku, 2006.

Matsunaga Toshio, 'Kaisetsu: Chenbāzu infomeshion to monbushō Hyakka zensho ni tsuite' [Commentary: On Chambers' Information and Monbushō's Encyclopedia], in William and Robert Chambers, eds., Chambers's Information for the People. Eureka Press, 2005.

Matsuyama Tōan, trans., Chigaku kotohajime [Introduction to Geography]. Keiō Gijuku Shuppankyoku, 1870.

Mitchell, S. Augustus, Mitchell's Geographical Reader: A System of Modern Geography, Comprising a Description of the World, with its Grand Divisions, America, Europe, Asia, Africa, and Oceania. Philadelphia: Thomas, Cowperthwait, 1840.

Miyake Yonekichi, Chūgaku Gaikoku chishi [Junior High School World Geography]. Kinkōdō Shoseki, 1896.

Nakagawa Kōichi, Kindai chirikyōiku no genrȳu [Origins of Modern Geographical Education]. Kokon Shoin, 1978.

Nakamura Goroku, ed., Chūtō chiri: Chirigaku Nihonshi ichi [Middle Level Geography: Japanese Geography 1]. Bungakusha, 1891.

Nakamura Kikuji, Kyōkasho no shakaishi Meiji ishin kara haisen made [Social History of School Textbooks from the Meiji Restoration to the End of WWII]. Iwanami Shoten, 1992.

Noguchi Yasuoki, Chūtō kyōiku Chiri kyōkasho [Middle Level Geography Textbook]. Narumidō and Meguro-shobō, 1896-97.

Okamura Hyōe, '“Konketsu” o meguru gensetsu' [Discourse on 'Mixed Race'], Kokusai Bunkagaku, 26 (2013): 23-47.

Ripley, William Z., The Races of Europe: A Sociological Study. New York: D. Appleton \& Company, 1899.

Russell, John G. 'Excluded Presence: Shoguns, Minstrels, Bodyguards, and Japan's Encounters with the Black Other', ZINBUN, 40 (2007): 15-51.

Sakamoto Hiroko, 'Chūgokushijō no jinshu gainen o megutte' [On the Concept of Race in Chinese History], in Takezawa Yasuko, ed., finshu gainen no fuhensei o tou: seiyōteki paradaimu o koete. Jinbun Shoin, 2005.

Sakano Tōru, Teikoku Nihon to jinruigakusha 1884 nen-1952 nen [Imperial Japan and Anthropologists, 1884-1952]. Keisō Shobō, 2005.

Satō Shōsuke, 'Watanabe Kazan to Takano Chōei'[Watanabe Kazan and Takano Chōei], in Satō Shōsuke, Uete Michiari and Yamaguchi Muneyuki, eds, Watanabe Kazan, Takano Chōei, Sakuma Shōzan, Yokoi Shōnan, Hashimoto Sanai. Iwanami Shoten, 1971.

Screech, Timon, Ōedo Ijin ōrai [The Coming and Going of Foreigners in Edo]. Maruzen, 1995.

Shibue Tamotsu, Kōtō shōgaku Bankoku chiri [Geography for Elementary School]. Hakubunkan, 1893.

Shihangakkō, Bankoku chishiryaku 1 kan [Condensed World Geography vol. 1], Monbushō, 1874.

Sitwell, O. F. G., Four Centuries of Special Geography: An Annotated Guide to Books That Purport to Describe All the Countries in the World Published in English Before 1888. Vancouver: UBC Press, 1993.

Sugawa Katahisa, Bankoku chirishi kanno-ichi [World Geography vol. 1]. Sugawa Katahisa, 1877.

Taguchi Ukichi, 'Kokugogaku yori kansatsu shitaru jinshu no shodai' [First Generation of a Race Considered from a Linguistic Viewpoint], Shigaku zasshi, 12:6 (1901): 1-28.

Taguchi Ukichi, 'Nihon jinshu ron' [On the Japanese Race], in Taguchi Ukichi, Rakutenroku. Keizai Zasshisha, 1898, 137-51.

Takahashi Yoshio, Nihon jinshu kairyōron [On Reform of the Japanese Race]. Ishikawa Hanjirō, 1884. 
Takezawa, Yasuko, 'Toward a New Approach to Race and Racial Representations: Perspective from Asia', in Yasuko Takezawa, ed., Racial Representations in Asia. Kyoto: Kyoto University Press/ Melbourne: Trans Pacific Press, 2011, 7-19.

Uchida Masao, Yochishiryaku [A Grammar of Geography for the Use of Schools]. Daigaku Nankō, 1871. Uryū Tora, Nihon kunizukushi [Account of the Country of Japan]. Izumiya Kichibē, 1872.

Wagatsuma, Hiroshi, 'The Social Perception of Skin Color in Japan', Daedalus, 96:2 (1967): 407-43.

Watanabe Kazan, 'Gaikoku jijōsho' [Report on Conditions in Foreign Countries], in Satō Shōsuke, Uete Michiari and Yamaguchi Muneyuki, eds, Watanabe Kazan, Takano Chōei, Sakuma Shōzan, Yokoi Shōnan, Hashimoto Sanai. Iwanami Shoten, 1971 [1839], 17-42.

Watanabe Kazan, 'Shinkiron' [A Private Proposal], in Satō Shōsuke, Uete Michiari and Yamaguchi Muneyuki, eds, Watanabe Kazan, Takano Chōei, Sakuma Shōzan, Yokoi Shōnan, Hashimoto Sanai. Iwanami Shoten, 1971 [1839], 65-72.

Watanabe Kazan, Saikō seiyō jijōsho [Introduction to the West, Revised Edition], in Satō Shosuke, Uete Michiari and Yamaguchi Muneyuki, eds, Watanabe Kazan, Takano Chōei, Sakuma Shōzan, Yokoi Shōnan, Hashimoto Sanai. Iwanami Shoten, 1971 [1839], 43-55.

Yamada Yukimoto, Shinchishi [New Geography]. Uehara Saiichirō, 1893.

Yamada Yukimoto, ed., Shinsen chiri shōshi kan-ni [Newly Compiled Elementary Account of Geography, vol. 2]. Kōfūkan, 1879.

Yamamuro Shin'ichi, Shiso kadai toshite no Ajia [Asia as an Object of Contemplation]. Iwanami Shoten, 2001.

Yazu Masanaga, Chūgaku Bankoku chishi [Junior High School World Geography]. Maruzen, 1896.

Yazu Masanaga, ed., Nihon teikoku seiji chiri [The Japanese Empire: Politics and Geography]. Maruzen Shōsha, 1893.

Yonaha Jun, 'Kindai Nihon ni okeru “Jinshu” kannen no hen'yō Tsuboi Shōgorō no 'Jinruigaku' to no kakawari o chūshin ni' [The Racialization of finshu: Tsuboi Shōgorō's Anthropology and the Concept of Race], Minzokugaku kenkyū, 68:1 (2003): 85-97.

Yun Kŏn-ch'a, Minzoku gensō no satetsu: Nihonjin no jikozōo [The Failure of the Minzoku Illusion: Japanese People's Self-Image]. Iwanami Shoten, 1994. 